\title{
MEDIAL MORAINES OF THE HAUT GLACIER D'AROLLA, VALAIS, SWITZERLAND: DEBRIS SUPPLY AND IMPLICATIONS FOR MORAINE FORMATION
}

\author{
By B. GOMEZ \\ (School of Geography, University of Oxford, Mansfield Road, Oxford OX1 3TB, England) \\ and R. J. SMALL \\ (Department of Geography, University of Southampton, Southampton SO9 5NH, England)
}

\begin{abstract}
The Haut Glacier d'Arolla displays three medial moraines: an ablation-dominant moraine east of the glacier centre line, an ice-stream interaction moraine west of the glacier centre line, and a medial-lateral supraglacial moraine complex along the western margin of the glacier. The eastern moraine is formed by the emergence of coarse angular clasts from a series of short longitudinal debris bands $1 \mathrm{~km}$ from the glacier terminus; this debris is derived from rock falls at the glacier head-wall, and follows a low-level transport path through the glacier. The western moraine is formed partly by the direct fall of weathered debris on to the ice surface at a point $2.6 \mathrm{~km}$ from the snout, but it receives further increments of sediment from extensive longitudinal englacial debris bands developed from the convergence of two ice streams with lateral englacial debris septa. The medial-lateral moraine complex is formed largely by rock falls from the western valley wall, but is also nourished by a debris layer developed at the base of the small tributary Glacier de la Mitre. This layer crops out at the eastern margin of the re- sultant inset ice stream, and releases more rounded, abraded and comminuted rock fragments to supplement the surface debris cover of supraglacial origin.
\end{abstract}

RÉSUMÉ. Les moraines médianes du Haut Glacier d'Arolla, Valais, Suisse: alimentation et implications sur la formation des moraines. Le Haut Glacier d'Arolla montre trois moraines médianes: une moraine d'ablation à l'est, une moraine de confluence au centre et un complexe morainique supraglaciaire médio-latéral le long de la rive occidentale. La moraine orientale est formée par l'émergence de fragments anguleux grossiers commençant par une série de courtes bandes longitudinales de débris à $1 \mathrm{~km}$ du front; ces matériaux proviennent de chutes de pierres au fond du cirque d'alimentation et suivent une ligne de courant profonde. La moraine suivante est en partie formée par la chute directe de débris météorisés sur le glacier à $2,6 \mathrm{~km}$

\section{INTRODUCTION}

The inter-relationships between the source and character of glacial debris and the morphology and development of medial moraines on temperate valley glaciers have been considered in two recent papers (Eyles and Rogerson, 1978; Boulton and Eyles, 1979). Two principal models of medial moraine formation have been postulated.

(1) Ablation-dominant ( $A D$ ) moraines are developed from englacial debris, of ten largely of supraglacial origin, which collects on the glacier surface in the firn zone (and is then incorporated within the ice as a result of succeeding winter snow accumulation) or falls into open crevasses (which are subsequently closed, giving rise to steeply dipping debris bands). The englacial debris is itself exposed again at the glacier surface, owing to ice ablation below the firn line, and, where it is concentrated into longitudinal or transverse "debris septa" within the du front mais est ensuite nourrie de sédiments intraglaciaires provenant de la confluence de deux courants de glace. La moraine médio-latérale est principalement formée à partir des éboulis de la rive occidentale, mais elle est également alimentée par une couche de débris formée à la base d'un petit affluent, le glacier de la Mitre. Cette couche affleure sur le bord oriental du courant de glace emboité et fournit des fragments de roche plus arrondis, usés, broyés s'ajoutant à la couverture d'origine supraglaciaire.

ZuSAMmenfassung. Mittelmoränen am Haut Glacier d'Arolla, Wallis, Schweiz: Schutt-Nachschub und Zusammenhänge der Moränenbildung. Der Haut Glacier d'Arolla weist drei Mittelmoränen auf: eine durch Ablation hervorgerufene Moräne östlich der Mittellinie des Gletschers, eine durch die Wirkung zwischen den Eisströmen aufgeschobene Moräne westlich dieser Linie und einen oberflächlichen Moränenkomplex am westlichen Gletscherrand. Die östliche Moräne wird durch den Austritt grober, eckiger Bruchstücke aus einer Serie kurzer, längslaufender Schuttbänder $1 \mathrm{~km}$ vom Gletscherende gebildet; dieser Schutt stammt vom Steinschlag an der Rückwand des Gletschers und folgt einer tiefgelegenen Transportbahn durch den Gletscher. Die westliche Moräne entsteht teilweise durch den direkten Fall verwitterten Schuttes auf die Eisoberflăche an einer Stelle mit 2,6 km Abstand von der Zunge, erhält jedoch weiteren Materialnachschub von ausgedehnten, längsgerichteten inneren Schuttbändern, die sich beim Zusammenfluss zweier Eisströme mit seitlichen Schutthüllen entwickeln. Der seitliche Mittelmoränenkomplex entsteht weitgehend durch Steinschlag von der westlichen Talflanke, wird jedoch auch durch eine Schuttschicht ernährt, die sich am Grunde des kleinen Nebengletschers de la Mitre entwickelt. Diese Schicht tritt am Ostrand des sich ergebenden Nebeneisstroms aus und gibt mehr gerundete, abgeschliffene und zerkleinerte Felsstücke frei, welche die oberflächliche Schuttdecke supraglazialen Ursprungs ergänzen.

glacier, gives rise to moraine ridges which, by the action of differential ablation, increase in prominence down-glacier.

(2) Ice-stream interaction (ISI) moraines are formed below the junctions of confluent glaciers, of ten from supraglacial debris which has accumulated on supraglacial lateral moraines above the junctions. Where the latter are below the firn line, the surface debris gives rise immediately to a medial moraine, which may again increase in relief down-glacier.

In reality, several variants of these two main types of medial moraine are identifiable. For example, ablationdominant moraines may form below the confluence of glaciers (where this occurs above the firn line), giving a type intermediate between $\mathrm{AD}$ and ISI moraines. Alternatively, ablation-dominant moraines may be formed down-glacier from bedrock protuberances, where subglacial 
debris is raised to an englacial position (and eventually exposed at the glacier surface by ablation) either as a result of shearing mechanisms (Souchez, 1967) or by the divergence of flow lines from the glacier bed owing to lateral ice compression in the lee of the obstacle (Boulton, 1978).

This paper is concerned primarily with an examination of the two main medial moraines of the Haut Glacier d'Arolla (Fig. 1); of these the western is evidently an ISI type, and the eastern evidently an AD type. Field study has

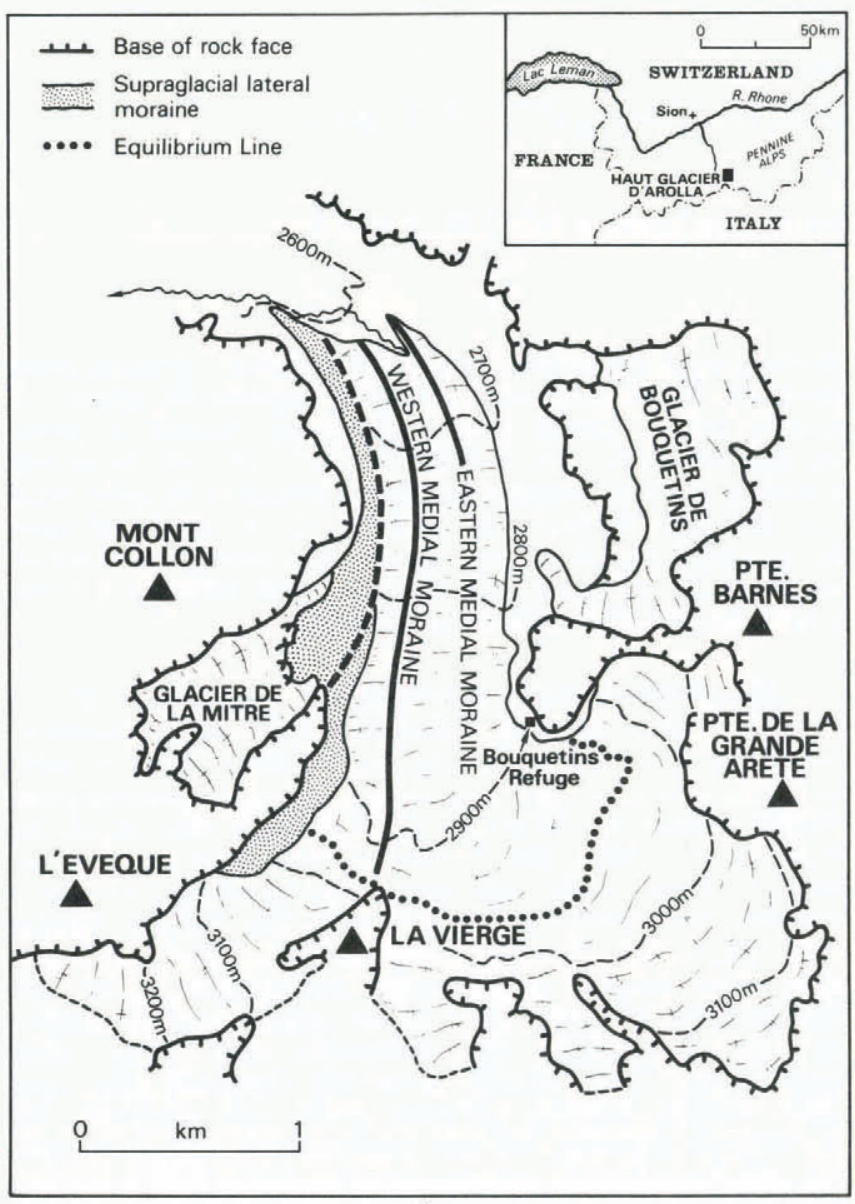

Fig. 1. Haut Glacier d'Arolla.

shown that both are "nourished", to a greater or lesser extent, by well-defined longitudinal debris bands (which constitute two distinct debris septa). Analysis of these bands has revealed the complex nature of the sediment-supply and debris-transport mechanisms associated with medial moraine formation on temperate valley glaciers. The paper also discusses a less distinct medial moraine formed at the confluence of the small Glacier de la Mitre and the Haut Glacier d'Arolla.

\section{FIELD SETTING}

The Haut Glacier d'Arolla is approximately $3 \mathrm{~km}$ in length and possesses a compound firn basin (95\% of which lies between $2875 \mathrm{~m}$ and $3100 \mathrm{~m}$ ), covering an area of about $3 \mathrm{~km}^{2}$. Within the basin there are three main elements: a relatively large accumulation area delimited by La Vierge in the south-west and the Pointe de la Grande Arête in the east; a smaller area in the form of the ice tongue between L'Evèque and La Vierge; and a still smaller area in the well-defined re-entrant to the south-west of Pointe Barnes. The Haut Glacier d'Arolla itself possesses a near-uniform, gentle long profile from the threshold of the firn basin to the snout (at approximately $2500 \mathrm{~m}$ ). A small tributary glacier, Glacier de la Mitre, joins the Haut Glacier d'Arolla from the west, beneath the eastern face of Mont Collon. No study of the mass balance or velocity distribution of the Haut Glacier d'Arolla has been made, though field observation over several years has shown that the equilibrium line lies mainly at a height of a little over $2900 \mathrm{~m}$.

The detailed morphology of the two main medial moraines of the Haut Glacier d'Arolla (the western extending the length of the glacier from the base of La Vierge, and the eastern "emerging" from the ice surface at about $1 \mathrm{~km}$ from the snout) has been described and discussed by Small and others (1979). During the 1983 ablation season, unusually favourable snow conditions permitted a close examination of the nature and sources of the sediment in these moraines, which revealed important new information.

(1) The eastern moraine is developed from large quantities of englacial debris. This emerges from the ice surface to form a number of relatively small, discrete sub-parallel ridges trending parallel to the centre line of the glacier (Fig. 2). However, these ridges quickly merge down-glacier to form one large moraine ridge with a maximum height of $18 \mathrm{~m}$ above adjacent bare ice. The

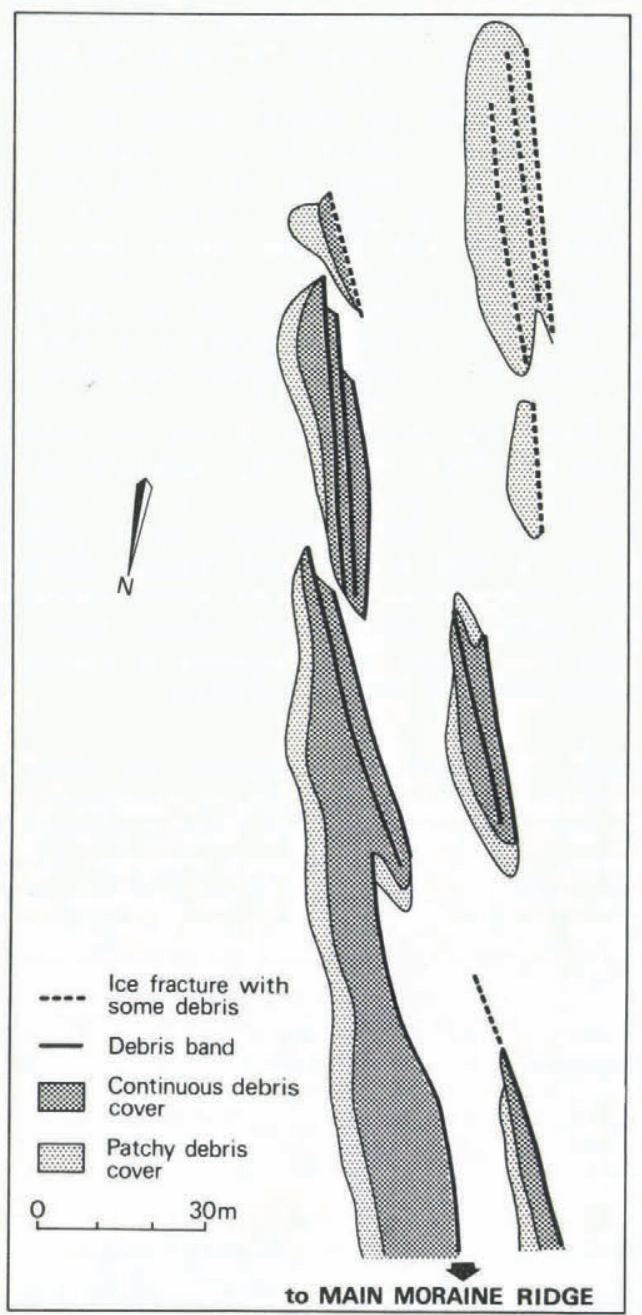

Fig. 2. Longitudinal debris bands and moraine ridges at the head of the eastern medial moraine, Haut Glacier d'Arolla.

longitudinal debris bands, which appear to supply the moraine in its entirety, are characteristically $20-40 \mathrm{~m}$ in length and sometimes form a crude en échelon pattern. Each band is less than $0.5 \mathrm{~m}$ in thickness (except where very large individual boulders are included), dips either vertically or at a very steep angle towards the centre of the glacier, is aligned with the dominant folia, and extends to an indeterminate depth. The debris within the bands lies almost entirely in the coarser size ranges (fine gravel to boulder; $2.0 \mathrm{~mm}$ to $>1 \mathrm{~m}$ ), is loosely packed, and is invariably angular or very angular (Fig. 3). The 


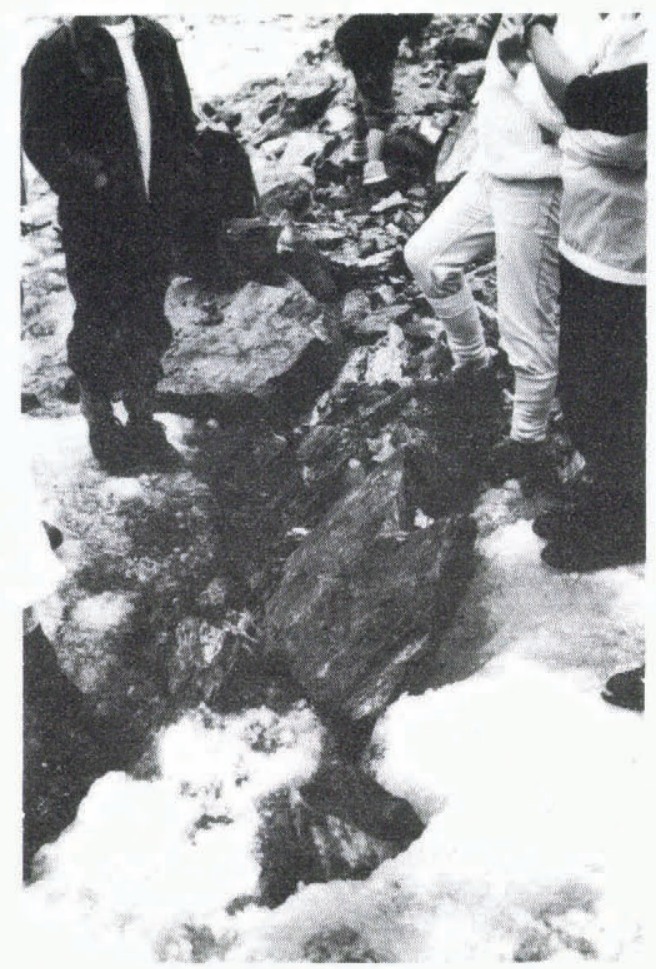

Fig. 3. Angular clasts emerging from a longitudinal debris band at the head of the eastern moraine, Haut Glacier d'Arolla.

lithology of the included fragments (schists and gneisses, comparable to exposures on the western face of the Pointe Barnes-Pointe de la Grande Arête ridge) suggests an origin in the eastern accumulation zone of the Haut Glacier d'Arolla.

(2) The western moraine commences approximately on the equilibrium line of the Haut Glacier d'Arolla, near to the foot of La Vierge. Immediately down-glacier from this peak, the moraine consists of two or three distinct but small ridges extending over a distance of $1.4 \mathrm{~km}$, but then merging to form one major ridge (attaining a maximum height of $11 \mathrm{~m}$ ). The moraine is clearly nourished in part by supraglacial debris (derived from the rapidly weathered schists on the flanks of La Vierge) but englacial sources also make a substantial contribution. The latter occur as two longitudinal debris bands up to $20 \mathrm{~cm}$ in thickness; at a point $500 \mathrm{~m}$ down-glacier from La Vierge, where the moraine is transected by crevasses, these near-vertical bands were observed to a depth in excess of $10 \mathrm{~m}$ (Fig. 4). Clearing of the superficial debris cover at various sites along the crests of the moraine revealed that the westernmost band (slightly the thicker) extends to within $750 \mathrm{~m}$ of the glacier terminus. The debris bands of the western moraine are aligned to the dominant folia, and the constituent particles are again predominantly angular and sub-angular. However, in contrast to the bands of the eastern moraine, the sediment here is quite densely packed and displays at times a clear stratification, comprising alternate layers of clear and sediment-rich ice. Appreciable quantities of finer material (silt to coarse sand; $0.63-2.0 \mathrm{~mm}$ ) are also present, though the particle-size distribution remains skewed towards the coarser size ranges. Indeed, tabular boulders, up to $3 \mathrm{~m}$ along the major axis, have been observed "emerging" from the ice surface along the outcrop of the major debris band.

\section{ORIGIN OF LONGITUDINAL DEBRIS BANDS}

(1) The longitudinal debris bands which form the eastern moraine of the Haut Glacier d'Arolla are interpreted as discrete, steeply dipping "tabular" bodies of englacial sediment which are being exposed at the ice surface by

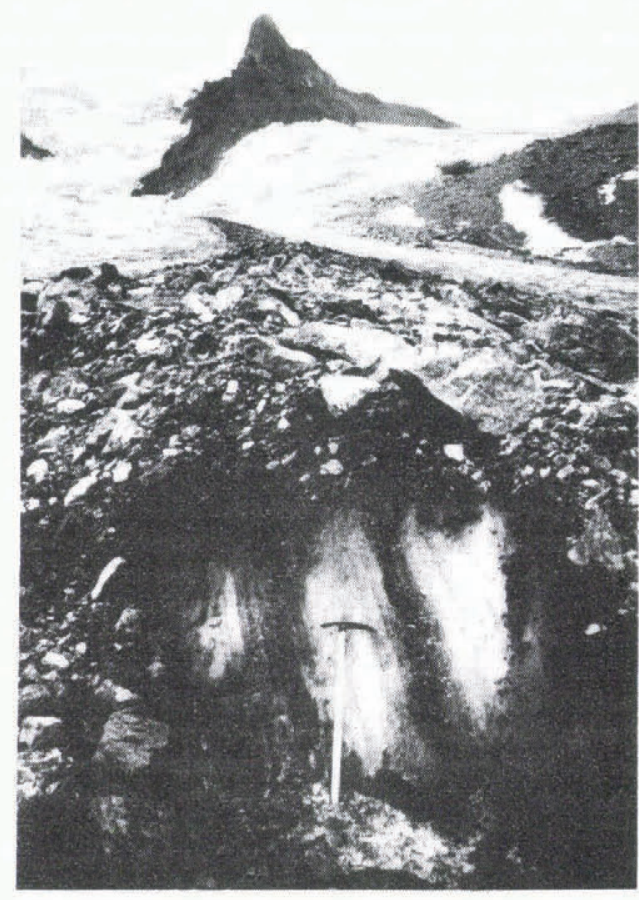

Fig. 4. Near-vertical longitudinal englacial debris bands, exposed by a transverse crevasse, western moraine, Haut Glacier d'Arolla.

substantial annual ablation (in the order of 5-10 m/year) In our view, the bands are "passive"; in other words, they do not involve the upward movement of debris either along shear planes or any other type of fracture. The precise mechanics of such a shearing process are far from clear and, in any case, the extreme angularity of the contained fragments is not consistent with the observed morphology and characteristics of subglacially derived and transported clasts (Boulton, 1978). The most likely mechanism to account for the debris bands is rock falls in the firn zone, resulting either from freeze-thaw weathering of supraglacial faces or discontinuous rock-mass failure (DRMF) of oversteepened sections of the valley head-wall (Addison, 1981). The resultant surface debris layers are then incorporated within the glacier by burial beneath annual layers of winter snow, and - as they are subsequently transported down-glacier - are transformed into a series of comparatively narrow bands parallel to the direction of glacier flow and dipping steeply inwards towards the centre line of the glacier Whatever the debris source, the disposition of the bands of the eastern moraine can be satisfactorily explained in terms of the model of foliation presented by Hooke and Hudleston (1978). The surface sedimentary accumulations, entrained initially in the firn zone in a position parallel to the ice surface, have been transported downwards into a position parallel to the glacier bed, and then rotated and thinned in the zone of simple shear close to the bed (Fig. 5). In the case of the Haut Glacier d'Arolla, the initial

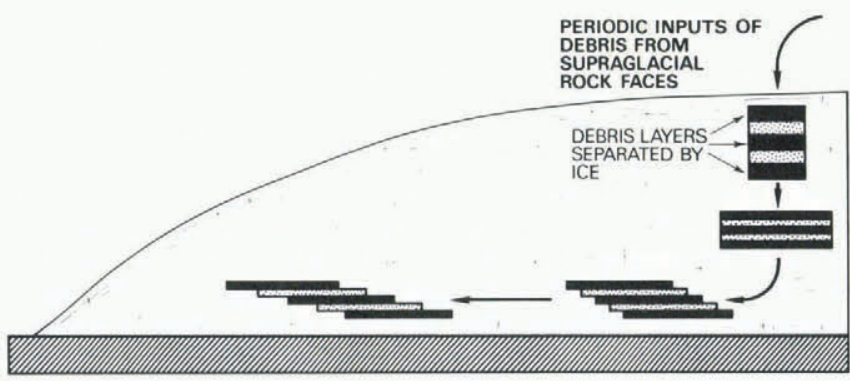

Fig. 5. Transfer of sedimentary layers (supraglacial debris and ice) through a glacier. 
convergence of flow in the eastern firn basin, and the "rotation" of flow through some 90-120 around the Bouquetins Refuge promontory, has produced transverse stresses within the ice which have served both to reorientate and enhance the dip of the debris bands.

(2) The debris bands which nourish the western moraine are more extensive and continuous features than those of the eastern moraine, though less numerous and less "debris-rich". The two main bands are clearly related to the confluence of the two major contributory ice streams from either side of La Vierge. At the latter point, flow lines which are immediately adjacent to the valley side-walls, and are associated with debris-enriched marginal ice, converge beneath the "head" of the media moraine (Fig. 6). The contained debris is visualized as (i) the product of entrainment of fragments falling from the

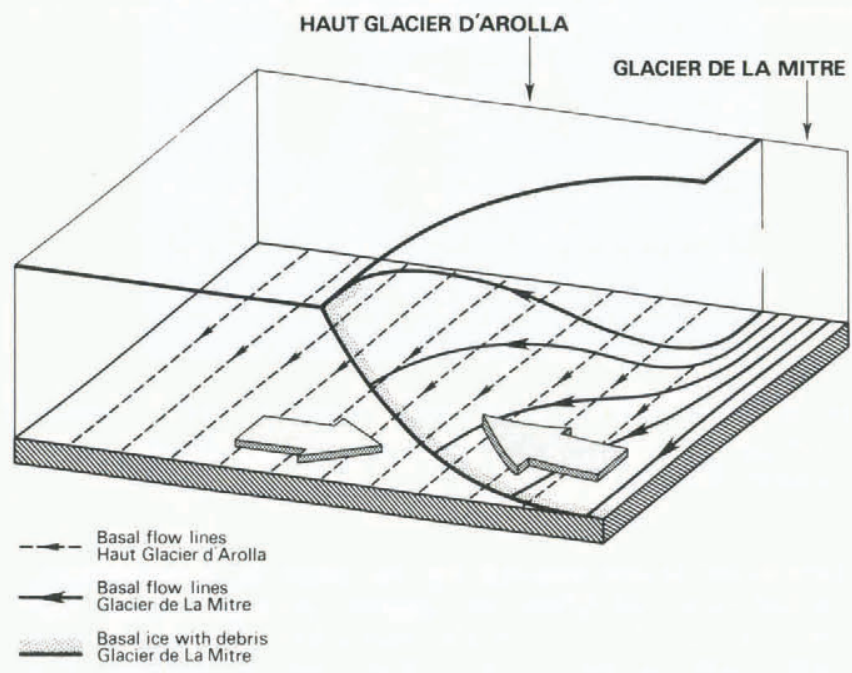

Fig. 6. Convergence of flow lines at La Vierge, Haut Glacier d'Arolla.

supraglacial valley walls, and (ii) sediment which is derived from glacial erosion or the comminution of supraglacial clasts along the side-wall/ice interface. The relative positions of the two principal bands, and the enhanced debris content of the western band, are consistent with development along the right-hand margin of the L'Evèque firn zone and the left-hand flank of the ice flow to the east of La Vierge.

\section{THE GLACIER DE LA MITRE MORAINE}

At the junction of Glacier de la Mitre and the Haut Glacier d'Arolla a medial moraine of the ISI type is formed. However, within a short distance it is "overwhelmed" by falls of supraglacial debris from the western valley wall above the Haut Glacier d'Arolla, and becomes part of the western supraglacial moraine complex of the latter. Although the bulk of the overlying debris of this moraine displays supraglacial characteristics (coarse and angular clasts in abundance), rounded, sub-rounded, and abraded stones and boulders are also much in evidence. Moreover, clearance of superficial debris from the underlying ice has revealed the presence of a $1 \mathrm{~m}$ thick, longitudinal debris band, which extends as far as the glacier snout (where it is revealed, fortuitously, in cross-section and appears to be dipping westward beneath overlying ice in the manner of a large shear plane) (Fig. 7). The sediment within this band is very densely packed, strikingly "stratified", and comprises rounded and sub-rounded clasts, and an abundance of particles in the silt- to coarse sand-size range $(0.63-2.0 \mathrm{~mm})$. Down-glacier of the confluence with Glacier de la Mitre, the Haut Glacier d'Arolla progressively narrows from a width of $750 \mathrm{~m}$ to less than $400 \mathrm{~m}$ in a distance of $1.5 \mathrm{~km}$. It appears that, owing to the lateral compressive stresses that this narrowing engenders, the "inset" ice stream (Sharp, 1948) derived from

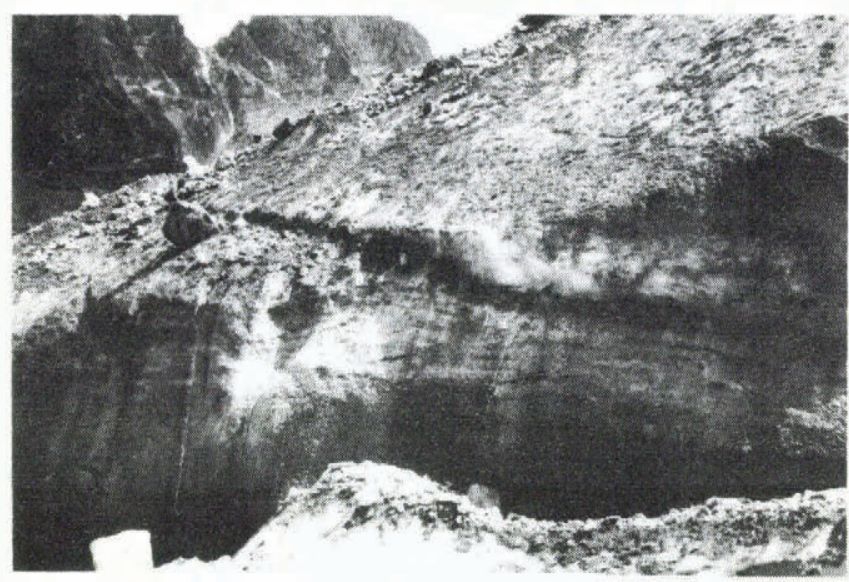

Fig. 7. Major debris band, comprising subglacial sediment, exposed at the snout of Haut Glacier d'Arolla.

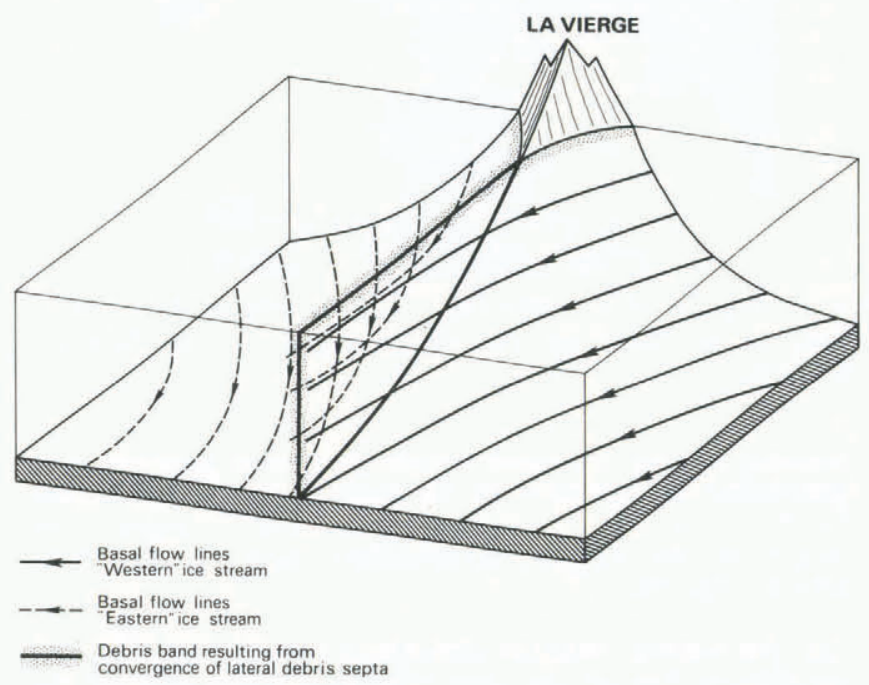

Fig. 8. Convergence of flow lines and uplift of subglacial sediment at the junction of Haut Glacier d'Arolla and Glacier de la Mitre.

Glacier de la Mitre is overriding the ice of the Haut Glacier d'Arolla in the manner shown in Figure 8. As a result, basal ice and contained sediments from Glacier de la Mitre are exposed at the surface as a longitudinal debris band, thus accounting for (i) the thickness and detailed character of the band (whose structure is suggestive of successive "freezings-on" of ice and sediment by basal regelation), and (ii) the manner in which debris is being squeezed out from the band (at some points compacted ridges of silt-sized material stand proud of the ice surface). We consider this to be an unusual example where a shearing mechanism (sensu lato) has resulted in the transfer of substantial quantities of subglacial debris to the ice surface.

\section{DEBRIS SUPPLY TO MEDIAL MORAINES: SUMMARY}

(1) The eastern medial moraine of the Haut Glacier d'Arolla is primarily supplied by englacial debris of supraglacial origin. The character of the englacial debris bands strongly indicates that the constituent clasts were initially deposited as discrete debris layers (probably from inf requent but large-scale rock falls) at the head of the firn zone. These surface-debris accumulations were then incorporated within the glacier, were rotated into their longitudinal form largely as a result of the interaction between the confluent flows of the eastern firn basin, and were progressively "tilted" to give the steep "inward" dips characteristic of the lower englacial debris bands of the 
Haut Glacier d'Arolla. That there were several distinct source areas for the debris is indicated by the lithological contrasts between some individual bands (for example, between the bands comprising iron-stained, highly fissile schists and those containing grey "unweathered" gneisses).

(2) The western medial moraine presents a more complex picture in terms of debris origin and supply. There is some direct nourishment of the moraine by falls of supraglacial debris to the base of $\mathrm{La}$ Vierge but also emergence of significant quantities of englacial debris from at least two longitudinal bands farther down-glacier. This englacial sediment is partly of supraglacial derivation, but - to judge from the morphology of the debris - was in part entrained at some depth along the side-wall/ice contact, where supraglacial debris was comminuted and additional debris resulted from glacial abrasion.

(3) The medial/lateral moraine complex on the western margin of the lower Haut Glacier d'Arolla displays contrasting characteristics in terms of superficial debris, owing to the combination of (i) supraglacial clasts derived directly from the valley wall, and (ii) subglacial debris from the basal ice of Glacier de la Mitre.

\section{IMPLICATIONS FOR MEDIAL MORAINE DEVELOP- MENT}

It is evident that the medial moraines of the Haut Glacier d'Arolla cannot be simply categorized in terms of the two models of moraine formation referred to in the introduction to this paper. Thus, although the debris forming the western moraine is at least partly incorporated

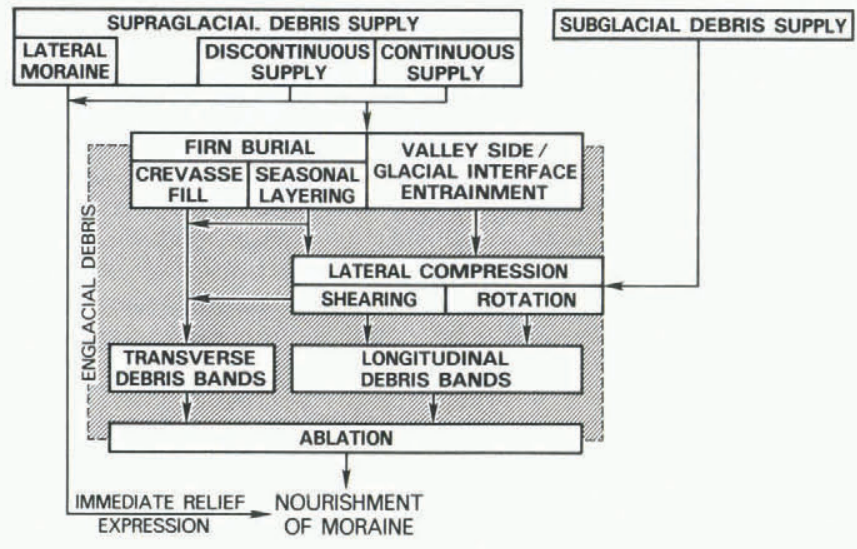

Fig. 9. The relationships between debris supply and entrainment, the formation of englacial debris bands, and medial/lateral moraine formation. above the firn line, along the margins of glaciers which eventually merge, neither the ablation-dominant or ice-stream interaction model adequately describes the dynamics of debris supply to the moraines. Rather, it is suggested, a greater emphasis should be placed on supply mechanisms (Fig. 9) than on moraine morphology. Since the latter is dependent on factors other than debris sources (such as superficial debris thickness, the process of differential ablation, and the effectiveness of lateral debris sliding on moraine slopes; Small and Clark, 1974), to focus on moraine form and dimensions merely obscures the true relationships between moraines and glacier-sediment dynamics.

\section{ACKNOWLEDGEMENTS}

This research was supported by a grant from the Royal Society to B.G. and R.J.S., and by a grant from Jesus College, Oxford, to B.G.

\section{REFERENCES}

Addison, K. 1981. The contribution of discontinuous rock-mass failure to glacier erosion. Annals of Glaciology, Vol. 2, p. 3-10.

Boulton, G.S. 1978. Boulder shapes and grain size distribution as indicators of transport paths through a glacier and till genesis. Sedimentology, Vol. 25, No. 6, p. 773-99.

Boulton, G.S., and Eyles, N. 1979. Sedimentation by valley glaciers; a model and genetic classification. (In Schlüchter, C., ed. Moraines and varves: origin, genesis, classification. Proceedings of an INQUA symposium on genesis and lithology of Quaternary deposits, Zürich, 10-20 September 1978. Rotterdam, A.A. Balkema, p. 11-23.)

Eyles, N., and Rogerson, R.J. 1978. A framework for the investigation of medial moraine formation: Austerdalsbreen, Norway, and Berendon Glacier, British Columbia, Canada. Journal of Glaciology, Vol. 20, No. 82, p. 99-113.

Hooke, R.L., and Hudleston, P.J. 1978. Origin of foliation in glaciers. Journal of Glaciology, Vol. 20, No. 83, p. 285-99.

Sharp, R.P. 1948. The constitution of valley glaciers. Journal of Glaciology, Vol. 1, No. 4, p. 182-89.

Small, R.J., and Clark, M.J. 1974. The medial moraines of the lower Glacier de Tsidjiore Nouve, Valais, Switzerland. Journal of Glaciology, Vol. 13, No. 68, p. 255-63.

Small, R.J., and others. 1979. The formation of medial moraines on Alpine glaciers, by R.J. Small, M.J. Clark, and T.J.P. Cawse. Journal of Glaciology, Vol. 22, No. 86, p. 43-52.

Souchez, R.A. 1967. The formation of shear moraines: an example from south Victoria Land, Antarctica. Journal of Glaciology, Vol. 6, No. 48, p. 837-43. 